\title{
UJI AKTIVITAS IMUNOGLOBULIN M (IgM) KELINCI JANTAN (Oryctolagus cuniculus) AKIBAT PENGARUH PEMBERIAN PRODUK MADU
}

\author{
Asriani Suhaenah, Nurul IImi Ainun Nissa \\ Fakultas Farmasi Universitas Muslim Indonesia \\ Email : asriani.suhaenah@umi.ac.id
}

\begin{abstract}
The objective was to study the effect of natural pure honey on the immunoglobulin $M$ (IgM) antibody activity against sheep red blood cells (SRBCs) antigen ini male rabbit (Oryctolagus cuniculus) using the hemoagglutination method. Three different honey products with 2,1 $\mathrm{ml} / \mathrm{kg}$ body weight given orally twice a day for 5 days. Then each animal was injected intraperitoneally with $2,8 \mathrm{ml}$ of $2 \%$ SRBCs. At day 7 after the immunization, serum were collected from the blood samples to know which highest dilution value of rabbit serum still showing agglutination reaction. The result of the the statistical analysis using the Complete Random Device (CRD) method and than continued with the Duncan's Multiple Range Test (DMRT) method shows that the administration of three different honey products significantly increase Immunoglobulin M (IgM) activity against SRBCs.
\end{abstract}

Key words : Honey, Hemaglutination, Rabbit

\section{PENDAHULUAN}

Madu adalah cairan kental yang berasal dari nektar pada tanaman berbunga yang dikumpulkan oleh lebah madu yang masih mengandung enzim diastase aktif (5). Madu merupakan gula invert (campuran dari glukosa dan fruktosa) yang larut dalam 14 sampai $20 \%$ air, serta asam organik, mineral dan vitamin dalam jumlah yang lebih kecil.

Imunoglobulin M (IgM), salah satu jenis Imunoglobulin, merupakan antibodi dalam respons imun primer terhadap kebanyakan antigen. IgM merupakan Ig yang paling efisien dalam aktivasi komplemen (jalur klasik). Kebanyakan sel B mengandung IgM pada permukaannya sebagai reseptor antigen. IgM dibentuk paling dahulu pada respons imun primer dibanding dengan IgG, karena itu kadar IgM yang tinggi dalam darah umbilikus merupakan petunjuk adanya infeksi dini. Telah dilaporkan bahwa pemberian madu secara oral menstimulasi produksi antibodi selama respon imun primer dan sekunder terhadap antigen thymus-dependent dan thymus-independent pada mencit. 
Lebih spesifik lagi telah dilaporkan bahwa madu secara positif mempengaruhi respon imun humoral yang dengan signifikan meningkatkan kadar IgM pada mencit yang diinfeksikan dengan Schistosoma mansoni.

Data hasil pengamatan yang diperoleh akan dianalisis dengan menggunakan analisis statistik sehingga akan diketahui apakah pemberian produk madu pada kelinci jantan (Oryctolagus cuniculus) secara oral akan meningkatkan aktivitas IgM. Akhirnya, dari hasil penelitian ini diharapkan dapat memberikan informasi kepada masyarakat terkait khasiat produk madu yang ada di pasaran dalam meningkatkan aktivitas $\lg \mathrm{M}$.

\section{METODE PENELITIAN}

\section{Alat dan Bahan yang Digunakan}

Alat-alat yang digunakan adalah gelas kimia $100 \mathrm{ml}$, gelas ukur $25 \mathrm{ml}$, jarum suntik, kateter, lemari pendingin, mouthblock, pengaduk elektrik, pipet mikro, pipet volume $1 \mathrm{ml}, 5 \mathrm{ml}$ dan 10 $\mathrm{ml}$, plat mikrotiter, sentrifus, timbangan analitik, timbangan gram (Ohauss).

Bahan-bahan yang digunakan adalah air suling, etanol $96 \%$, Kelinci jantan (Oryctolagus cuniculus), larutan Buffer Fosfat Saline, produk madu AS, produk madu EK, produk madu MR, sel darah merah domba (SDMD) $2 \%$.

\section{Pengambilan Sampel}

Sampel yang akan diteliti adalah berbagai produk madu murni yang beredar di kota Makassar, Sulawesi Selatan. Produk madu dibagi menjadi 3 kelompok, yaitu produk pabrikan luar negeri, pabrikan dalam negeri dan yang masih diproduksi secara sederhana. Produk madu yang akan diteliti dipilih secara random. Dari 3 produk luar negeri, yaitu AS, LN, GA dipilih produk AS. Dari 5 produk pabrikan dalam negeri, yaitu MN, MK, MR, AB dan MS dipilih MR. Dan dari 4 produk madu yang diproduksi secara sederhana, yaitu madu dari daerah KK, SM, SP dan EK, dipilih madu dari daerah EK.

\section{Pembuatan Larutan Buffer Fosfat} Saline (BFS) dan Suspensi Sel Darah Merah Domba (SDMD)

\section{Penyiapan Larutan BFS}

Larutan BFS disiapkan dengan terlebih membuat larutan $A$ yaitu larutan $\mathrm{NaH}_{2} \mathrm{PO}_{4} \cdot \mathrm{H}_{2} \mathrm{O} 1,38 \mathrm{~g} / \mathrm{l}$ dan $\mathrm{NaCl} 8,3 \mathrm{~g} / \mathrm{l}$ dan larutan $\mathrm{B}$ yaitu larutan $\mathrm{NaH}_{2} \mathrm{PO}_{4} 1,42 \mathrm{~g} / \mathrm{l}$ dan $\mathrm{NaCl}$ $8,5 \mathrm{~g} / \mathrm{L}$. Selanjutnya $280 \mathrm{ml}$ larutan A ditambahkan pada $720 \mathrm{ml}$ larutan B untuk mendapatkan $1000 \mathrm{ml}$ larutan BFS dengan pH 7,2. 
Larutan BFS lalu disterilkan dalam autoklaf pada suhu $121^{\circ} \mathrm{C}$ selama 15 menit.

\section{Penyiapan Suspensi SDMD 2\%}

Darah domba di tampung dalam tabung bersih, kering dan telah disterilkan yang berisi serbuk EDTA sebagai antikoagulan. Untuk $1 \mathrm{ml}$ darah domba, diperlukan $1 \mathrm{mg}$ EDTA. Sel darah merah domba (SDMD) di pisahkan dari plasmanya dengan pemusingan pada kecepatan 1500 rpm. Selanjutnya sel darah merah di cuci dengan menambahkan PBS (Phosphat Buffered saline) dalam jumlah besar dan tabung berisi suspensi tersebut dibolak balik beberapa kali dan dipusingkan kembali. Lakukan pencucian paling sedikit 3 kali. Setelah selesai, BFS dibuang dan diperoleh SDMD 100 \%. Kemudian pada SDMD 100\% tadi tambahkan BFS dengan volume sama hingga diperoleh suspensi SDMD 50\%. Siapkan antigen yang akan digunakan dengan mengencerkan $0,4 \mathrm{ml}$ suspensi SDMD $50 \%$ dengan 9,8 $\mathrm{ml}$ BFS sehingga diperoleh $10 \mathrm{ml}$ suspensi antigen (SDMD $2 \%$ ).

\section{Pemilihan Hewan Uji}

Hewan uji yang akan digunakan adalah kelinci jantan (Oryctolagus cuniculus) dengan berat $2.5-3.0 \mathrm{~kg}$ yang dewasa dan sehat.

\section{Penyiapan Hewan Uji}

Disiapkan 8 ekor kelinci jantan yang dibagi atas 4 kelompok. Tiap kelompok masing-masing terdiri dari 2 ekor. Kelinci dipuasakan 8 jam sebelum diberi perlakuan.

\section{Uji Pendahuluan}

Sebelum dipuasakan 8 jam terlebih dahulu dilakukan uji pendahuluan aktifitas IgM dengan melakukan uji aglutinasi pada kelinci terhadap SDMD 2\%.

\section{Perlakuan Terhadap Hewan Uji}

\section{Kelompok I :}

Kelinci jantan diberi air suling dengan volume $2,1 \mathrm{ml} / 1,5 \mathrm{~kg}$ bobot badan secara oral setiap 2 kali sehari, pagi dan malam selama 6 hari. Setelah 6 hari, kelinci diimunisasi dengan suspensi SDMD $2 \%$ dengan volume 2,78 $\mathrm{ml} / 1.5 \mathrm{~kg}$ robot badan secara intraperitonial.

\section{Kelompok II}

Kelinci jantan diberi larutan madu produk AS dengan volume 2,1 $\mathrm{ml} / 1,5 \mathrm{~kg}$ bobot badan secara oral 2 kali sehari, pagi dan malam selama 6 hari. Setelah 6 hari, kelinci diimunisasi dengan suspensi SDMD $2 \%$ dengan 
volume $2,78 \mathrm{ml} / 1.5 \mathrm{~kg}$ bobot badan secara intraperitonial.

\section{Kelompok III}

Kelinci jantan diberi larutan madu produk MR dengan volume 2,1 $\mathrm{ml} / 1,5 \mathrm{~kg}$ bobot badan secara oral 2 kali sehari, pagi dan malam selama 6 hari. Setelah 6 hari, kelinci diimunisasi dengan suspensi SDMD $2 \%$ dengan volume $2,78 \mathrm{ml} / 1.5 \mathrm{~kg}$ bobot badan secara intraperitonial.

\section{Kelompok IV}

Kelinci jantan diberi larutan madu produk EK dengan volume 2,1 $\mathrm{ml} / 1,5 \mathrm{~kg}$ bobot badan secara oral 2 kali sehari, pagi dan malam selama 6 hari. Setelah 6 hari, kelinci diimunisasi dengan suspensi SDMD $2 \%$ dengan volume $2,78 \mathrm{ml} / 1.5 \mathrm{~kg}$ bobot badan secara intraperitonial.

\section{Pengambilan Sampel Darah}

Pada hari kelima setelah imunisasi, darah diambil secara intravena pada telinga kelinci, lalu dibiarkan membeku/menggumpal pada suhu kamar selama 1-2 jam yang selanjutnya dilakukan pemusingan dengan sentrifuge pada kecepatan 3000 rpm selama 10 menit dan diambil serumnya (supernatan).

\section{Uji Aglutinasi}

1. Serum yang diperoleh selanjutnya diencerkan secara "double dilution" $1 / 4,1 / 8,1 / 16,1 / 32,1 / 64,1 / 128$, 1/256, 1/512 dengan BFS ,sebanyak $50 \mu$ l untuk

2. setiap sumur pada plat mikrotiter (Well plate 96).

3. Pada tiap sumur ditambahkan 50 $\mu l$ suspensi sel darah merah domba $2 \% \mathrm{v} / \mathrm{v}$ lalu diaduk rata (digoyang-goyang) selama 5 menit.

4. Selanjutnya diinkubasi pada $37^{\circ} \mathrm{C}$ selama 60 menit dan didiamkan semalam pada suhu kamar.

5. Dilakukan pengamatan titer imunoglobulin $\mathrm{M} \quad(\lg \mathrm{M})$ yaitu pengenceran tertinggi dari serum darah mencit yang masih dapat mengaglutinasi sel darah merah domba.

\section{Pengumpulan dan Analisis Data}

Data diperoleh dari hasil pengamatan pengenceran tertinggi serum yang masih menunjukkan aglutinasi. Selanjutnya data tersebut dianalisis secara statistik.

\section{HASIL PENELITIAN}

Data Uji aktivitas immunoglobulin $\mathrm{M}$ ( $\lg \mathrm{M})$ sebelum dan setelah pemberian produk madu AS, MR dan EK 2 kali seharí dengan volume 2,1 $\mathrm{ml} / \mathrm{kg}$ bobot badan (setara 2 sendok makan) berdasarkan titer 
imunoglobulin $\mathrm{M}$ ( $\lg \mathrm{M})$ pada kelinci $2 \% \mathrm{v} / \mathrm{v}$ adalah sebagai berikut : jantan 5 hari setelah diberikan SDMD

Tabel 1. Hasil Pengamatan Uji Aglutinasi Sebelum Diberikan Perlakuan

\begin{tabular}{|c|c|c|c|c|}
\hline \multirow{2}{*}{ Perlakuan } & \multicolumn{4}{|c|}{ Titer Imunoglobulin M (IgM) } \\
\cline { 2 - 5 } & Hewan I & Hewan II & Hewan III & Hewan VI \\
\hline Replikasi 1 & $1 / 4$ & $1 / 4$ & $1 / 4$ & $1 / 4$ \\
\hline Replikasi 2 & $1 / 8$ & $1 / 4$ & $1 / 4$ & $1 / 4$ \\
\hline Replikasi 3 & $1 / 4$ & $1 / 4$ & $1 / 4$ & $1 / 4$ \\
\hline
\end{tabular}

Tabel 2. Hasil Pengamatan Uji Aglutinasi Setelah Diberikan Perlakuan

\begin{tabular}{|c|c|c|c|c|}
\hline \multirow{2}{*}{ Perlakuan } & \multicolumn{4}{|c|}{ Titer Imunoglobulin M (IgM) } \\
\cline { 2 - 5 } & Hewan I & Hewan II & Hewan III & Hewan VI \\
\hline Replikasi 1 & $1 / 8$ & $1 / 32$ & $1 / 32$ & $1 / 64$ \\
\hline Replikasi 2 & $1 / 8$ & $1 / 32$ & $1 / 32$ & $1 / 32$ \\
\hline Replikasi 3 & $1 / 8$ & $1 / 32$ & $1 / 64$ & $1 / 64$ \\
\hline
\end{tabular}

\section{PEMBAHASAN}

Secara umum, di Indonesia terdapat 3 kelompok madu yang diproduksi, yaitu produk luar negeri, dalam negeri dan madu yang diproduksi secara sederhana. Produk madu yang berasal dari luar negeri adalah produk madu yang diimpor dari luar Indonesia dan peredarannya di Indonesia telah mendapat izin dari Departemen Kesehatan RI. Produk madu yang berasal dari dalam negeri adalah produk madu yang dibuat dalam negeri Indonesia dan telah mendapat izin dari Departemen Kesehatan RI untuk diperjualbelikan. Sedangkan madu yang dibuat secara sederhana adalah madu yang dibuat oleh masyarakat lokal menggunakan peralatan dan cara yang sederhana dan belum mendapatkan izin dari Departemen Kesehatan RI.

Dengan adanya perbedaan kondisi alam dan cara produksi, tentu saja akan tedapat perbedaan di antara ketiga kelompok tersebut. Di antaranya perbedaan khasiat yang diberikan.

Yang menjadi fokus utama pada penelitian ini adalah melihat sejauh mana pengaruh pemberian produk madu yang ada di Indonesia terhadap peningkatan aktivitas imunoglobulin M (lgM). Berdasarkan penelitian yang telah dilakukan oleh beberapa peneliti, di antaranya AlJabri dan Ali A, Al-Waili, N.S. dan Afruz Haq serta Maghraby dan Hassan Sohair A, telah memperlihatkan peningkatan yang signifikan terhadap 
kadar IgM setelah pemberian madu secara oral pada mencit $(1,9,10)$.

Sebelum diberikan produk madu, pada setiap kelinci dilakukan uji pendahuluan aglutinasi untuk mengetahui titer imunoglobulin $\mathrm{M}$ awal sebelum diberikan produk madu.

Dari hasil pengamatan titer aglutinasi setelah pemberian produk madu, data menunjukkan peningkatan aktivitas imuniglobulin $M$ (IgM) pada pemberian produk madu. Pada kelompok kontrol memberikan nilai titer rata-rata $1 / 8$, sedangkan pada kelompok perlakuan madu AS, MR dan EK memberikan nilai rata-rata berturut-turut 1/32; 1/38,4 dan 1/48.

Berdasarkan analisis statistika dengan menggunakan metode Rancangan Acak Lengkap (RAL) dan Analisis Sidik Ragam (ASR) memperlihatkan bahwa pemberian produk madu memberikan efek yang sangat nyata terhadap peningkatan aktivitas Imunoglobulin M (IgM), yang dapat dilihat dari nilai $F$ hitung yang lebih besar dari $\mathrm{F}$ tabel.

Analisis perbedaan antar perlakuan pada data titer Imunoglobulin M (IgM) menggunakan uji Beda Nyata Jarak Duncan (BNJD) antara perlakuan kontrol negatif dan kelompok perlakuan dengan pemberian madu AS, MR dan EK memperlihatkan selisih yang sangat nyata ( sangat signifikan) yaitu secara berturut-turut 1,$21 ; 1,41$ dan 1,61, yang berarti terjadi peningkatan aktivitas Imumoglobulin M (IgM) karena terjadi peningkatan titer. Sedangkan perbandingan antar kelompok yaitu dengan pemberian madu AS, MR dan EK tidak memperlihatkan perbedaan yang nyata (tidak signifikan). Ini tampak dari selisih yang diberikan yaitu AS dan MR terdapat selisih 0,2; AS dan EK terdapat selisih 0,4; MR dan EK terdapat selisih 0,2 .

Ketika hasil uji hemaglutinasi setelah pemberian produk madu dibandingkan dengan uji aglutinasi pendahuluan, maka tampak dengan jelas adanya peningkatan titer ratarata yang memperlihatkan bahwa pemberian madu mampu meningkatkan aktivitas imunoglobulin M (IgM). Yaitu produk AS dari $1 / 4$ menjadi $1 / 32$, produk MR dari $1 / 4$ menjadi $1 / 38,4$ dan produk EK dari $1 / 4$ menjadi $1 / 48$.

Dari penelitian ini dapat dinyatakan bahwa pemberian madu AS, MR dan EK dapat meningkatkan respon imun antibodi imunoglobulin $M$ ( $\operatorname{lgM})$, sebagaimana yang dijelaskan di atas, dengan adanya peningkatan titer antibodi yang dibandingkan dengan uji 
pendahuluan aglutinasi pendahuluan dan kontrol.

Berdasakan hasil dari pengamatan, di antara ketiga produk madu yang digunakan, diketahui bahwa yang memberikan hasil yang terbaik dalam meningkatkan kadar imunoglobulin adalah madu EK.

Setidaknya ada dua faktor yang mempengaruhi kualitas dan khasiat dari madu, yaitu kondisi alam dan tahapan produksi produk madu.

Adanya perbedaan kondisi alam akan mempengaruhi kualitas madu yang dihasilkan. Misalnya, daerah yang memiliki kelembaban yang lebih tinggi akan menyebabkan kadar air dalam madu akan lebih tinggi (lebih encer) sehingga mempengaruhi konsentrasi madu. Sehingga madu yang lebih kental akan mengandung lebih banyak zat gizi dibandingkan dengan madu yang lebih encer dalam volume yang sama.

Jenis bunga yang menjadi sumber pakan lebah juga sangat menentukan khasiat yang akan dihasilkan oleh lebah. Misalnya, lebah yang pakan utamanya adalah bunga kopi akan menghasilkan madu yang menimbulkan rasa kantuk. Bahkan ada pula madu yang beracun jika pakan lebahnya berasal dari bunga rhododendron. Jenis pakan juga menentukan rasa dari madu, misalnya rasa asin jika berasal dari bunga jamblang, rasa pahit jika berasal dari bunga mahoni ,madu rasa coklat jika berasal dari bunga pohon coklat dan lain sebagainya (3).

Jenis lebah penghasil madu juga menentukan khasiat dan kualitas madu yang dihasilkan. Khusus di Indonesia, kebanyakan peternak madu umumnya menggunakan jenis Apis melifera karena kemampuannya menghasilkan jumlah madu yang lebih banyak dari jenis lebah lain. Lebah dari genus Trigona akan menghasilkan madu yang rasanya asam.

Adapun terkait dengan tahapan produksi produk madu, meliputi pemanenan, lama penyimpanan, dan pengemasan.

Waktu pemanenan sebaiknya dilakukan pada saat musim nektar telah berakhir 2-3 minggu. Dan pada saat pemanenan harus diperhatikan apakah sel-sel yang mengandung madu dalam sarang lebah telah tertutupi lilin. Karena kondisi ini mengindikasikan bahwa madu telah siap untuk dipanen.

Madu yang ingin dikemas sebaiknya jangan terlalu lama disimpan. Karena semakin lama disimpan maka senyawa dalam madu sedikit-demi sedikit akan menguap 
karena dalam madu terdapat senyawa yang mudah menguap. Sehingga madu yang baik adalah madu yang baru dipanen. Sehingga semakin cepat produk madu tersebut sampai ke tangan konsumen maka akan semakin baik khasiat yang akan diperoleh.

Terkait warna madu, di antara ketiga produk madu tersebut terdapat perbedaan warna. Produk MR memiliki warna coklat gelap dibandingkan produk AS. Sedangkan produk EK memiliki warna yang paling cerah. Perbedaan warna ini di tentukan oleh kandungan mineral, jenis pakan dan cara pengolahan madu seperti ekstraksi madu dan pemanasan.

\section{KESIMPULAN}

Berdasarkan hasil penelitian dan analisis data secara statistika, maka disimpulkan bahwa madu yang diteliti yaitu madu AS, MR dan EK dapat meningkatkan aktivitas imunoglobulin $M(\lg M)$ dengan titer rata-rata secara berurutan yaitu 1/32. $1 / 38.4$ dan $1 / 48$.

\section{DAFTAR PUSTAKA}

Al-Jabri, Ali A., 2005, Honey, Milk and Antibiotics,http://www.academi cjournals.org/AJB, diakses 6 Agustus 2007

Anonim, 2006, Sweet Honey, www.jphpk.gov.my/English/
Oct06\%2015a. htm, diakses 30 Juli 2007

Suranto, A. 2005. Khasiat dan Manfaat Madu Herbal. Cetakan ke-2. Agromedia Pustaka. Jakarta. 25-35.

Susilo, 2006, Keajaiban Madu, www.habbat.com/madu/index 2.php? option $=$ com content $\&$ do $\mathrm{pdf}=$ $\underline{1 \& \mathrm{id}=21} \quad-$, diakses $18 \mathrm{Juli}$ 2007

Pusat Perlebahan Apiari Pramuka. 2003. Lebah Madu : Cara Berternak dan Pemanfaatan. Penebar Swadaya. Jakarta. 77.

Rantam, A.F.,2003., Metode Imunologi:, Airlangga University Press., Surabaya.

Levinson, Warren, 2004, Medical Microbiology \& Immunology : Examination \& Board Review, Eight Edition, The McGraw-Hill Companies, Inc., United States of America. 414-417

Bratawidjaja, K., 2004, Immunologi Dasar, Edisi II, Fakultas Kedokteran Universitas Indonesia, Jakarta, 19, 78, 82

Al-Waili, N.S., Afruz Haq, 2004, Effect of Honey on Antibody Production Against ThymusDependent and ThymusIndependent Antigens in Primary and Secondary Immune Responses, http://www.liebertonline.com/ doi/abs/10.1089/jmf.2004.7.49 1, diakses 18 Juli 2007

Maghraby, A.S., Hassan Sohair A., 2005, Effect of antioxidative 
properties of honey on Schistosoma mansoni-infected mice, www.direct.bl.uk/ research/4C/1C/RN173823369 .html, diakses 18 Juli 2007

Standar Nasional Indonesia 01-35452004. 2004. Madu. Badan Standardisasi Nasional. Jakarta. 1-13.

Warisno. 1996. Budidaya Lebah Madu. Kanisius. Yogyakarta. 35, 46.

Sumoprastowo, R.M. 1993. Beternak Lebah Madu Modern. Bharata. Jakarta. 42, 48.

Fessenden, R.J. 1996. Dasar-dasar Kimia Organik. Terjemahan Oleh Sukmariah Maun. 1997. Binarupa Aksara. Jakarta. 595-600

Sihombing, D.T. 1997. Ilmu Ternak Lebah Madu. Gajah Mada University Press. Yogyakarta. 32

Murtidjo, B.A. 1994. Memelihara Lebah Madu. Kanisius. Yogyakarta. 59-61

Kresno, S. 1996. Imunologi: Diagnosis dan Prosedur Laboratorium, Edisi ketiga. Fakultas Kedokteran Universitas Indonesia. Jakarta. 4,26-29, 271

Subowo, 1993, Imunobiologi, Angkasa Bandung, Bandung. 8, 110111
Clancy, J. 2000. Basic Concepts in Immunology. McGraw-Hill Companies. Singapore. 19, 20

Janeway, C.A., Paul Travers, 1997, Immunobiology, Third Edition, Garland Publishing Inc, New York. G:9

Barrer, J. 1988. Textbook of Immunology. Fifth edition. C.V. mosby Company. USA. 40

Anonim. 2006. Structure of Immunoglobulin.http://www.cat .cc.md.us/courses/bio141/lecg uide/humoral/antibodies/abydi versity/abydiversity.html. Diakses 24 Mei 2006.

Rose, N. 1973. Principles of Immunology. Maacmillan Publishing CO. New york. 124

Roitt, I. 1994. Essential Immunology. Eight edition. Black Well Scientific Publications. London. 43

Malole, M B. M., Pramono, C. S., 1989, Penggunaan Hewanhewan Percobaan di Laboratorium, Institut Pertanian Bogor, 105

Manggau, M. A., Bariun, H., 2007, Penuntun Praktikum Imunologi II, Edisi ke-2, Universitas Hasanuddin. 